\title{
KASPAR HAUSER: DE UMA CADEIA A OUTRA ${ }^{1}$
}

\section{KASPAR HAUSER: FROM ONE PRISON TO ANOTHER}

\author{
João Carlos Cattelan \\ UNIOESTE - Universidade Estadual do Oeste do Paraná
}

\begin{abstract}
RESUMO: Este estudo tem como objetivo fazer uma análise, dentre outras tantas possíveis, do filme O Enigma de Kaspar Hauser, de Werner Herzog, produzido na Alemanha em 1974. Para um comentarista do filme, o diretor propõe ao espectador um questionamento sobre se seria possível civilizar alguém que tenha tido contato com uma determinada cultura fora do tempo previsto. Defende-se, aqui, que não é esta a problemática com a qual Herzog ${ }^{2}$ está às voltas: entende-se que o diretor efetivamente realiza uma reflexão de caráter sociológico, visando a demonstrar que o percurso percorrido pelo protagonista (e pelos homens em geral) o leva de uma cadeia a outra. Uma delas, a primeira (uma cadeia física, espacial e material), limita os passos a serem dados e as figuras geométricas a serem desenhadas com o movimento corporal; a outra, a segunda (uma prisão simbólica calcada em condições de verossimilhança), limita as opções de valores que se pode ter e os princípios axiológicos que se devem partilhar. Acredita-se que a primeira prisão, visível na seqüência de fotogramas que alcança o olho do espectador, refere-se à construção de uma série de "metáforas" destinada a ser sobre-determinada pelo efeito de sentido de que a prisão sobre a qual efetivamente se
\end{abstract}

\footnotetext{
${ }^{1}$ Embora haja um estilo relativamente canônico com que um texto do tipo científico é apresentado, em geral contendo uma seção que arrebanha alguns dos aspectos teóricos que o sustentam, vou me permitir apenas fazer referência aqui aos autores com quem julgo ter os maiores débitos para a realização deste trabalho. São eles: Pierre Bourdieu (1999), para quem a sociedade se pauta num conjunto de pressupostos imperativos, que se abate sobre todos e limita suas ações; Cornelius Castoriadis (1982), para quem a sociedade é resultado de um processo de instituição imaginária, cujo resultado se autonomiza e aliena os seus membros; e Norbert Elias e John Scotson (2000), para quem a sociedade se divide entre os que se acham estabelecidos e podem ditar as formas de comportamento e os recém chegados (outsiders) que devem agir conforme os valores instituídos. Mas, principalmente (e o leitor que já se deparou com este autor perceberá imediatamente o débito para com ele) o suporte deste estudo (pretensamente um ensaio) busca em Michel Foucault seus insights mais significativos. As obras cruciais tomadas como amparo teórico desse autor são Vigiar e punir (1999), A ordem do discurso (1996) e Microfisica do poder (1999). Para ele, uma das características da sociedade é o fato de ela funcionar como um cárcere que prende a todos e delimita as suas opções de ação, desenvolvendo um sistema panóptico de controle e observação dos seus membros. A outra é o fato de o discurso ser controlado por uma série de princípios de rarefação, impedindo que seus membros possam dizer qualquer coisa em qualquer lugar. Para esse controle sobre o agir e o dizer, a sociedade teria desenvolvido um sistema de poder ramificado e micro-físico, usando a todos e a cada um para a manutenção e a reiteração dos seus valores. De modo geral, são estas as percepções gerais e os sustentáculos fundamentais que dão a base de apoio para o desenvolvimento deste estudo. Outros insights são tomados, en passant, de outros autores e o débito para com eles é reconhecido nas referências bibliográficas.

${ }^{2}$ Atente-se já de início que, ao fazer referência a Herzog, colocando-o como o eixo de referência para a produção dos efeitos de sentido, não se está pensando no enunciador como o ser empírico que teria vivido na Alemanha num determinado tempo e espaço, mas no enunciador que se manifesta a partir das marcas textuais disseminadas ao longo do filme e que permitem uma projeção sobre o seu projeto de significação.
} 
fala é aquela produzida pela sociedade que enreda seus membros, fazendo-os participar de uma doxa comum à qual só é possível se render e aceitar.

\begin{abstract}
This study has the objective of analysing the film The Enigma of Kaspar Hauser, by Werner Herzog, produced in Germany in 1974. For a film critic, the director proposes to the audience a question about the possibility of civilizing somebody that has had contact with a certain culture after the adequate time. It is defended in this work that this is not the problematic with which Herzog is concerned: one understands that the director effectively carries through a reflection of a sociological character, aiming to demonstrate that the journey the protagonist (and men generally) makes takes him from one prison to another. The first (a physical, spatial and material prison), limits the steps to be taken and the geometric figures to be drawn with corporal movements; the second one (a symbolic arrest based in conditions of verisimilitude), limits the options about values that can be done and the axiological principles that one is forced to share. The first prison, visible in the photogram's sequence that reaches the eye of the audience, is a construction of a series of metaphors destined to be determined by the effect of sense that the prison one really talks about is that produced by the society that entangles its members, obligating them to participate of a common doxa they have no other option than to comply with and accept.
\end{abstract}

PALAVRAS-CHAVE: Kaspar Hauser; discurso; efeito de sentido; injunção.

KEY-WORDS: Kaspar Hauser; discourse; effect of sense; injunction.

\title{
1. Introdução
}

O "Enigma de Kaspar Hauser", um filme que recebeu o Prêmio Especial do Júri num dos festivais de Cannes, "é uma das obras primas do cineasta alemão Werner Herzog" (comentário retirado da sinopse que se encontra na capa do DVD, em versão restaurada e remasterizada). Na contracapa, consta: "Baseando-se em registros históricos, Herzog nos conta o estranho caso de Kaspar Hauser, um jovem encontrado perdido em uma praça em 1828. Ele não falava e não conseguia ficar em pé. Passara a vida inteira trancado num porão. Seria possível civilizá-lo?" Nesse breve resumo de apresentação ao espectador, o comentarista apresenta uma sinopse do enredo que se desenvolverá: uma trama de efabulação envolvendo um personagem misterioso que, um dia, é descoberto num porão, sem ter tido contato nenhum com a civilização e se encontrando, portanto, num estado comportamental próximo ao do animal, sem nada que o aproxime de um ser humano normal. Kaspar não fala (emite grunhidos), não caminha (senta e deita), não se "alimenta" (come o pão e a água que deixam à noite), não conhece ser humano e não chora: enfim, é uma tábula rasa infensa à agressão e à carícia. Não conhece o medo, a ameaça e o perigo: não possui, em resumo, nenhuma "cultura".

Estrelado por Bruno S. e Walter Ladengarst, o filme tem a direção de arte de Henning Von Gierke, a fotografia de Jörg Schmidt-Reitwein, a música de Popol Vuh e a produção, o roteiro e a direção de Werner Herzog. Com a classificação de "para maiores de 14 anos, com temas e diálogo adulto" e com áudio em alemão, o filme é apresentado como pertencente ao gênero drama, foi filmado em 1974, na Alemanha, e tem a duração de 109min.

Concorda-se com a sinopse do filme, quando afirma que "O enigma de Kaspar Hauser é um filme indispensável para educadores, psicólogos e admiradores do bom cinema". E por que não para semioticistas e analistas do discurso? Pode-se afirmar, com uma certa obviedade, que, dependendo da linha teórica que o psicólogo ou o educador defendam, certos aspectos serão realçados e outros silenciados, isto sem levar em conta o sem número de outros 
pontos de vista que teriam o que dizer sobre o filme, o que só enobrece o objeto em foco, dada a profusão de enunciados que ele permite e a pluralidade de efeitos de sentido que possibilita.

Nessa miríade de possibilidades de respostas a Herzog (e ao comentarista que fez a sinopse), tem-se, aqui, o objetivo específico de analisar o filme do ponto de vista da seleção de alguns dos recursos utilizados para compô-lo, com vista a determinar os efeitos de sentido que geram, apostando-se que tais recursos concorrem harmoniosamente para a construção de um fio de sentido distinto daquele que aparece na capa do DVD. Entende-se que a manutenção desse fio revela que a trajetória que Kaspar Hauser (e todo ser humano ${ }^{3}$, portanto, pois é possível considerar que a sociedade em que o protagonista circula simula metonimicamente a sociedade humana em geral) o leva de uma prisão a outra, mais reticulada, tentacular e enoveladora do que a prisão inicial em que se encontrava. $O$ percurso de Kaspar Hauser, desse ponto de vista, leva-o de uma prisão física e espacial a uma cadeia de nós que se tecem nos intercâmbios sociais e que, estando estabelecida, fixa os limites dentro dos quais ele (e o homem, por conseqüência) pode se movimentar.

Quer-se, já de início, marcar posição em relação ao elaborador da sinopse sobre se seria possível civilizar Kaspar Hauser, questão com a qual Herzog estaria às voltas. Entende-se que o problema a que Herzog se dedica não é este, mas o de se interrogar sobre como a sociedade age em relação aos seus membros. Essa problemática chega ao espectador por meio da voz do protagonista que narra uma história e diz não saber como terminá-la, isto é, ele sabe que os homens que visualiza em sua história saíram do deserto (metáfora do vazio cultural), formaram caravanas (metáfora da constituição de tribos), venceram montanhas (metáfora da conquista do espaço) e formaram cidades. O que o narrador não consegue responder é como essa história terminará, fim que desejaria diferente daquele que presencia, por perceber que a sociabilidade que se constituiu não é, humanamente, a mais adequada.

Como não pode pretender que a história humana seja orientada para uma meta cada vez mais aprimorada e para a busca da perfeição, Herzog, por meio de Kaspar Hauser, não consegue prever como esta história terminará, pode somente indicar que o caminho que ela percorre, valendo-se de um processo de condicionamento, sujeição, submissão e rarefação do homem, é aquilo que se traça como a hipótese a ser demonstrada neste estudo. A questão, portanto, que o filme propõe é: poderão os homens constituir outra sociabilidade, diferente daquela que discrimina, rejeita e separa o diferente? A sociedade que encarcera os seus membros, que os acondiciona em torres com janelas estreitas e que esmaga seus nomes próprios, espezinhando-os, pode ser diferente? Ela poderá abrir mão da busca de domínio e de controle? O dilema de Herzog refere-se, pois, à possibilidade de elucidação de uma cultura e não à de alguém ser iniciado nela, quando parece ter passado o momento oportuno. É este o fio da meada que se pretende construir doravante.

\section{O movimento analítico}

Uma das primeiras imagens com que o espectador se depara é a de uma canoa que desliza sobre as águas de um rio, sendo os dois canoeiros observados da margem por uma lavadora de roupas, que os contempla com um sorriso de estranhamento, ao mesmo tempo em que lhes endereça um olhar irônico e desconfiado. Por meio do rio que percorre um trajeto, revelando uma face límpida cujo manto impávido esconde segredos infinitos, dos canoeiros,

\footnotetext{
${ }^{3}$ Está-se partindo da hipótese de que os recursos utilizados para a produção do filme concorrem para a criação de um efeito de sentido metonímico e metafórico em relação à sociedade humana, que se caracteriza, grosso modo, pela gestão do olhar, do pensar, do dizer e do sentir, buscando inibir que o aleatório e o fortuito possam tomar lugar. Neste sentido, o filme Kaspar Hauser representaria a sociedade humana vista em escala microscópica.
} 
que não podem trilhar outro caminho a não ser o que os conduz no sentido da correnteza do rio e a quem não resta outra opção a não ser a submissão à vontade da corrente inexorável, e da lavadeira (embaixatriz momentânea do olhar de Herzog) que os contempla de forma cética e cínica, pode-se afirmar que o diretor do filme busca distanciar-se da sociedade que contempla, pondo-a sob suspeição. E lança sobre ela um olhar indagador, no sentido de buscar deslindar as forças que a atravessam e dão a sustentação que faz com que canoas frágeis que conduzem serem mais frágeis ainda não naufraguem e não sejam engolidas pelas entranhas ameaçadoras e vorazes que as amparam. No mar da vida em que seres se encontram mergulhados e raramente logram vir à superfície e contemplar o espaço em que se encontram imersos, a lavadeira (e Herzog com ela), por se situar fora dele, pode captá-lo em suas características e submetê-lo à limpeza, torcendo-o até um ponto não sabido.

No intervalo de tempo que vai de $2^{\prime} 03$ a 2'44 ${ }^{4}$, a câmera focaliza um campo de trigo que é açoitado pelo vento e que é curvado pela força da ação poderosa que o acomete. Antes de fazer a análise da cena, cabe tecer alguns comentários sobre o Pentecostes, cerimônia ligada à colheita do trigo. É exatamente nessa etapa do ano religioso que é dito ao espectador que Kaspar foi encontrado. Enquanto a Páscoa era uma festa caseira, Colheita ou Semanas ou Pentecostes era uma celebração agrícola, originalmente, realizada na roça, no lugar onde se cultivava o trigo e a cevada, entre outros produtos agrícolas. Posteriormente, essa celebração foi levada para os lugares de culto, particularmente, o Templo de Jerusalém. Os muitos relatos bíblicos não revelam, com clareza, a ordem do culto, mas é possível levantar alguns passos dessa liturgia: a) a cerimônia começava quando a foice era lançada contra as espigas e deve-se lembrar que se devia respeitar o direito de respiga dos pobres e estrangeiros; b) a cerimônia prosseguia com a peregrinação para o local de culto; c) o terceiro momento se dava pela reunião do povo trabalhador com suas famílias, amigos e estrangeiros. Não se podia trabalhar, pois aqueles dias eram considerados um período de alegria e ação de graças pela proteção e cuidado de Deus. No local da cerimônia, o feixe de trigo ou cevada era apresentado como oferta a Deus, o doador da terra e a fonte de todo bem. Os celebrantes alimentavam-se de parte das ofertas trazidas pelos agricultores.

Redirecionado para a prática religiosa, o Pentecostes passou a designar o momento de descida do Espírito Santo sobre os apóstolos, levando-os a falar diversas línguas e adquirindo, assim, o poder de sair pelo mundo e pregar o Evangelho aos diferentes povos. Já que Kaspar Hauser aparece na cidade no dia de Pentecostes e ele é portador de um outro discurso, ainda por se fazer, poder-se-ia pleitear que ele é o porta-voz de uma possibilidade de revisão da sociedade com que vai se deparar, fato que não acontece, porque a alteração de doxas cristalizadas é uma tarefa para titãs. Contrariamente, portanto, a se tornar o espírito novo e a nova mentalidade redentora de uma cultura, Kaspar se torna o Pentecostes ligado à festa pagã, trigo a ser moído, triturado, amassado e que recebe nova modelagem: voz que, podendo ser nova, é domada, domesticada e dominada, enfim, silenciada.

À tentativa de se pôr na posição vertical, por meio de um movimento em espiral que visa a tirá-lo da dobra em que se encontra, o vento o faz dobrar-se, forçando-o a se curvar até o ponto desejado e buscado pela força que o assola: cabe colocá-lo de joelhos, não lhe permitindo ocupar a posição erecta. No trigo que se torna farinha destinada a transformarse em pão, depois de ser massa de modelar forjada pela mão do homem, há uma metáfora para a atividade realizada pela sociedade sobre o homem: essa ação se dá por meio de uma ventania assoladora (a força do discurso) que açambarca a todos, fazendo-os desaparecer na massa "amorfa" de um rio, cujas entranhas não mais são reveladas, passando a constituir um

\footnotetext{
${ }^{4}$ Sempre que se usar este recurso de marcação, está-se indicando para o leitor o intervalo fílmico que está sendo tomado como foco de observação e análise.
} 
terreno remetido à zona do silêncio que, por ser silêncio, torna-se mais forte, não mais podendo ser questionado ou polemizado. Eis o homem equiparado ao trigo: ele é, como Kaspar, a matéria bruta a ser vergada, o produto natural a ser triturado nas moendas que o capturam e a massa a ser modelada e transformada em alimento de uma máquina voraz e faminta. Ao homem, nascido para andar em pé, sob esta ação vigorosa, resta apenas se submeter à força do vento que o açoita, sendo obrigado a se tornar parte de uma massa difusa, homogênea e monótona: sem rosto e sem identidade. O seu "destino" é se tornar um cavalo, suporte de arreios que o manipulam e o conduzem para uma meta traçada desde sempre: a sua história é historicizada.

Dos 3'50 aos 4'47, a câmera focaliza Kaspar Hauser que, numa posição próxima ao do que se chamaria estar sentado, "brinca" com um cavalo de madeira, fazendo-o movimentar-se de acordo com sua vontade e o enovelando com as tiras de pano que tem à disposição. $\mathrm{O}$ brinquedo parece ter sido preso por uma aranha excessivamente possessiva, que o enreda e o envolve numa trama de fios das quais não mais poderá livrar-se. Kaspar é a aranha que enovela o brinquedo numa teia da qual, em breve, tornar-se-á objeto. A violência de golpes e de movimentos a que o brinquedo é submetido será reduplicada em breve, quando ele será o cavalo a ser encilhado e manietado como a marionete com a qual passa seus momentos agora. Assim como o cavalo com que Kaspar Hauser se delicia deve se submeter às vontades do seu amo, ele em pouco tempo será domesticado, aceitando ser vestido, manietado, enovelado e envolvido por uma teia apertada, da qual não poderá se livrar, devendo tornar-se o dócil cavalo domesticado que aceita, desconhecedor da força que possui, ser o cabide sobre o qual os arreios se ajustam, o meio de transporte para o dono e a força que movimenta a máquina despótica e tirana que o desumaniza. Não é à toa que o primeiro brinquedo de Kaspar é um cavalo, também não o é o fato de 'horse' ser a primeira palavra que ele aprende, assim como não é gratuito que, dos 20’28 aos 20'40, quando Kaspar está paralisado frente à cidade com que se depara pela primeira vez, a câmera focalize repetidamente ao fundo uma carroça junto à qual se encontra uma parelha de cavalos encilhados. Assim como eles, Kaspar (e o homem em geral) é o cavalo a ser domesticado, encilhado, manietado, enovelado e preso em teias tecidas com nós coesos e justos, que não lhe permitem horizontes mais amplos do que os que lhe dão. Nos cavalos presos à máquina produtiva, pode-se detectar ainda a submissão a uma forma de relação dos homens com o mundo do trabalho: uma relação exploratória e desumanizadora. Entende-se que o uso do cavalo, por demais repetitivo para ser fortuito, corrobora a tese assumida: o autor pretende mostrar como a sociedade funciona e não interrogar-se sobre se é possível iniciar alguém tardiamente numa cultura desconhecida.

Dos 6’50 aos 9'00, o homem que encontrou Kaspar Hauser, e que irá abandoná-lo mais tarde, leva ao esconderijo um banquinho de três pernas ${ }^{5}$, sobre o qual coloca um conjunto de folhas de papel. Ele faz com que Kaspar pegue o lápis que lhe põe na mão e começa a ensiná-lo a escrever o nome, ao mesmo tempo em que repete ao seu ouvido que aquilo se chama escrita: uma escrita que vem impor todo um conjunto de valores sobre a suposta natureza inocente, pura e ingênua de Kaspar. Uma série de efeitos emana destas imagens. $\mathrm{O}$ banco de três pernas permite inferir que, doravante, Kaspar será a parte do banco usada para sentar e sobre ele se inscreverão valores e ditames lavrados em leis destinadas a domesticar os usos de si. Pode-se pensar que, na vida futura, Hauser não terá mais o direito de

\footnotetext{
${ }^{5}$ Dever-se-ia notar que o banco de três pernas remete interdiscursivamente à Santíssima Trindade, na qual Kaspar Hauser seria o portador do Espírito Santo e que, não sendo aceito entre os seus, sendo esfolado e triturado nas moendas de trigo, é um espírito a ser silenciado e submetido aos valores da doxa reinante. Qualquer aproximação entre ele e Jesus Cristo, crê-se, não terá sido mera coincidência.
} 
se erguer sobre as duas pernas que possui: até sobre elas, a domesticação interferirá e dará um sentido. Ele deverá unir às pernas naturais uma terceira, imposta pela escrita da cultura e pela carga social de que o nome próprio será receptáculo. A sua sustentação não lhe será dada pelas pernas que o corpo físico lhe concede, mas pela perna que efetivamente o sustenta: a da cultura. Por outro lado, no gesto de pôr na mão do personagem o lápis e levá-lo a traçar um nome (que é imposto e não escolhido), cuja atividade ocorre por meio da imposição de uma mão sobre a outra, pode-se inferir o efeito de sentido de que cada um deve viver o papel que outras mãos impuseram sobre quem está aprendendo a viver em sociedade.

O nome que Kaspar recebe é imposto e o percurso lavrado sobre o papel, como a atividade de cultivar o trigo sobre a terra, refere-se ao caminho que ele deverá seguir pela vida: sem escolhas. O traçado no papel que desenha um nome próprio, na verdade, é a identidade lavrada a ferro sobre aquele que, folha em branco, recebe a sua do exterior. A escrita, portanto, mais do que permitir a liberdade de se constituir sobre o papel em branco é o resultado de injunções impostas sobre aquele que se depara com um mundo desconhecido. Por fim, há que se refletir sobre a atribuição de um nome próprio ao protagonista. Mais do que uma forma de lhe permitir se diferenciar dos demais, donde resultaria uma identidade e a possibilidade de realização de uma subjetividade peculiar e de uma subjetividade própria, o nome aponta para uma forma de controle sobre aquele a quem cabe o rótulo diferenciador que permite buscá-lo, fazendo-o submeter-se à doxa estabelecida. O nome próprio, ao lado de outros elementos, permitirá que a sociedade vigie Kaspar Hauser (e cada um dos membros), podendo distinguir aqueles que merecem menos ou mais atenção, em função da docilidade ou da rebeldia que manifesta. Não se pode esquecer que, enquanto aprende a escrever o nome, Kaspar ouve a palavra 'cavalo' e brinca com o que está ao seu lado, enredilhado. Eis alguns efeitos de sentido que parecem corroborar a denúncia ácida de Herzog.

Dos 14’00 aos 15’30, após ter passado por algumas lições básicas sobre como postar o corpo, rabiscar o nome e se tornar dócil como um cavalo domesticado, Kaspar Hauser é retirado de seu cativeiro, não antes de ser "algemado", é levado a uma montanha distante dos olhos curiosos e é iniciado na difícil arte de ficar ereto e caminhar conforme os outros homens. É posto, então, de pé, sendo obrigado a se movimentar de forma compassada, ou seja, passo a passo, com um pé sendo posto sobre o solo após o outro. Seja pela forma combinada com que deve fazê-lo, seja pelo ritmo que é imposto sobre o movimento que deve realizar ou pela condução imitativa a que é submetido, Kaspar aprende como o seu corpo deve ser conduzido, a que postura ele deve obedecer e que conjunto de fios o dirigem e o forçam a usar o corpo de uma certa forma. A observação dessas marcas textuais permite que se observe a forma como o aprendizado se processa: Hauser é obrigado a ficar de pé e a caminhar sob os "chutes" do seu "professor".

Assim como os animais são domesticados e aprendem a se conduzir por meio de agressões físicas, a denúncia de Herzog é feita no sentido de alertar para o fato de que Kaspar (o homem) é "educado" por meio da violência e da imposição de antolhos que o obrigam a se mover no rumo traçado por quem chegou antes e foi submetido ao mesmo processo de tortura. Deve-se perceber que o diretor do filme aponta para o fato de que mesmo a atividade aparentemente mais natural do homem resulta de um processo de aprendizado e de modelagem à luz de uma cultura. Devem ser lembrados, aqui, os esforços e as falhas de uma criança que começa a caminhar, para perceber que essa atividade não é natural, mas o resultado de uma imposição sobre a posição e a condução do corpo. Seja, pois, pelo nome que o localiza ou pela forma de conduzir o corpo, que o caracteriza, Kaspar tem as suas opções cerceadas.

Dos $17^{\prime} 00$ aos $18^{\prime} 00$, momentos antes de ser lançado na cidade em que passará 
a viver, a câmera focaliza o vale que circunda o futuro habitat de Kaspar e o mostra organizado em áreas rigorosamente divididas em dois grupos: espaços ocupados por formas de plantio distintas e espaços à espera da exploração futura. Percebe-se, no passeio que é realizado pela câmera, o deslocamento que ela realiza entre áreas lavradas e cultivadas e outras à espera de que a mão humana as submeta à sua ordem. E outra vez se pode ouvir a voz autoral $^{6}$ equiparando o protagonista à área inculta e intocada que será submetida à "lapidação" e à devastação que se produz sobre os elementos naturais ${ }^{7}$. Assim como a terra inexplorada sobre a qual se deixam marcas de uma passagem, rastros de uma pegada humana ou de uma atividade produzida pela mão do homem, Kaspar é a página em branco sobre a qual a civilização imprimirá sua marca, fazendo-a passar de floresta densa, verde e caótica, ao chão vermelho aplainado e submetido a uma ordem, que espera que a semente seja lançada e produza os frutos matemáticos previstos, imperiosamente lógicos: que esta seja a lógica ditada pela doxa pouco importa, cabe obedecer a ela. Eis outra imposição à qual Kaspar não mais será infenso: o espaço tem uma disciplina. A força que açoita e verga o trigo é a mesma que açoita e conduz os corpos a uma distribuição regrada e ordenada que faz com que cada um se localize no espaço a que pertence. Àqueles cuja ação redunda num corpo conformado e, por isso, numa "alma" adequada, o mundo se rende e reverencia, dando-os como normais. Aos demais, não massificados e que não atendem aos estereótipos, cabe eliminar: é o que acontece a Kaspar. Por não atender ao desejo dos demais (não porque não se esforçasse e não buscasse aprender música, alimentar-se adequadamente, higienizar-se do modo previsto, vestir-se da forma prevista, aprender lógica e falar "corretamente", dentre outras tentativas de adequação à chamada normalidade) e por se manter, até certo ponto, individual e diferente, ele deve ser exterminado: ele é uma ameaça à doxa espaço-corporal dominante.

Dada ao espectador esta visão panorâmica que focaliza o percurso que Kaspar traçará em seguida, adentrando um espaço que ainda não o conhece e não lhe é conhecido, ele é conduzido à cidade e abandonado numa praça pública, mantendo em sua mão uma carta de apresentação que diz quem é, de onde vem e o que pretende ser. Agora, ele está à mercê de um conjunto de episódios, que seriam apenas fatos fortuitos e aleatórios, se já não estivessem previstos numa grade classificatória e traçada, que prevê o que dizer sobre os usos do corpo que se podem fazer e a ocupação do espaço que pode ser realizada. No momento de entrada nesse local estranho, algumas escolhas efetuadas pelo diretor do filme devem ser salientadas, para entender que elas corroboram a hipótese assumida neste estudo: o trajeto percorrido por Kaspar o leva de uma cadeia a outra: uma física, a outra simbólica.

Sem nada dizer, ou comentar, ou explicar, ou esclarecer, dos $18^{\prime} 02$ aos $18^{\prime} 09$, a opção do cineasta faz com que a câmera fixe o relógio existente no alto da torre que domina a cidade inteira. Essa "perda de tempo", que dura 7 segundos ininterruptos e focaliza apenas o relógio no alto da torre da igreja, pode ser relacionada à busca da criação do efeito de sentido de que Kaspar está sendo introduzido num mundo regrado pelo tempo cronológico, ditador absoluto do que se deve fazer a cada momento: quando se alimentar, fazer higiene, dirigir-se às outras pessoas, abastecer-se de provimentos, fazer negócios, dispor do tempo dos outros. Enfim, Hauser (e o espectador com ele) acaba de ser apresentado a uma máquina ditatorial,

\footnotetext{
${ }^{6}$ Está-se entendendo autor não como o ser empírico que pré-existe ao discurso e que explicaria as conexões e relações estabelecidas, mas como a imagem textual e discursiva que emerge do discurso como princípio de unificação dos enunciados, como voz que se responsabiliza pelos pontos de vista assumidos e como foco de olhar que capta o objeto de discurso a partir de um determinado horizonte de apreciação. Neste sentido, a autoria resulta de um processo de inscrição discursiva que assume pontos de vista e os constrói responsavelmente.

${ }^{7}$ Embora essa afirmação tenha um caráter bastante determinista e fatalista e a sua formulação, inclusive, deixe entrever uma relação interdiscursiva com o comportamentalismo behaviorista, com o qual se pode ou não concordar, este parece ser um efeito de sentido possível de ser detectado a partir das marcas textuais utilizadas.
} 
fria e calculista, que impõe um conjunto de regras sobre o uso das horas e de si mesmo: um acordo. Doravante, cabe conduzir a vida, fazendo colar a cada fração de tempo a atitude esperada, o que pode significar alimentar-se sem vontade, fazer higiene sem precisar, silenciar querendo falar, falar querendo silenciar: uma série de interdições ocorrem a partir da criação de um eixo temporal e, diante delas, não há fuga, pois há uma sociedade erguida para exigir o seu cumprimento. Contra o tempo desregrado e vivido ao sabor das "horas", Kaspar deverá se conduzir pelo cronograma pronto e validado: eis o tempo organizado para que as pessoas se "organizem". E eis o ingrediente perverso que essa organização gera: uma máquina destinada a dar ao homem o domínio sobre a natureza, um meio auxiliar de organização, é alçada à condição de imposição do modo como se deve conduzir a travessia da vida pelas horas que transcorrem.

Dos 18:10 aos 18:46, Kaspar é conduzido por vielas, esquinas, construções, ruas e calçadas, até que seja colocado em praça pública, sendo ali abandonado. O traçado percorrido por Kaspar pode ser lido como o percurso que deverá dar, a seguir, à sua vida: as estradas estão previstas. O caminho tortuoso e árido lavrado sobre as pedras é o caminho impositivo que se aplicará ao seu corpo. Ele só poderá se mover atendendo aos trajetos destinados para a condução dos corpos. Nova rede de coerção se abate sobre o protagonista: se, antes, ela era de natureza temporal, agora ela se refere ao uso espacial. Deve-se notar que Kaspar viveu, até então, num espaço uniforme, homogêneo e invariável: ele sabia onde estava e reconhecia cada canto. Na nova visão, a partir de agora, o espaço se coloca sob outro rigor, "racionalmente" calculado e culturalmente disciplinado, sob tal força injuntiva que, como ele não era um membro daquela sociedade (ele é o diferente, o anormal, o alienígena - ele não está entre os seus), restou aos cidadãos, já de posse do seu recorte sobre este mundo, destinar a Kaspar, como local de "uso", descanso e vida, a estrebaria, entre os cavalos, local idêntico ao de sua origem. Parece que se pode ouvir Herzog afirmando que, para a sociedade, os "anormais" (de 'anormais' para 'animais', a distância sonora é curta) não têm lugar. Investigado na estrebaria sobre sua origem e não tendo como "catalogá-lo" (pode-se lembrar aqui dos catálogos de fotos usados pelos policiais para a identificação de supostos marginais), o local destinado a Kaspar é uma torre, local de vagabundos, desocupados e desconhecidos: como não se encaixa numa categoria "normal", Kaspar vai para a vala comum dos "marginais", recebendo como tratamento "devido" o espetáculo circense que se desdobra nas "visitas" que recebe e nos olhares por meio da janela gradeada na porta da sua cela (dos 30:45 aos 31:10). Embora sobrem espaços monumentais ao redor da e na cidade, a cadeia é o destino de Hauser: ali ele deve permanecer, porque é isto que se encontra dentro dos ditames sociais para o uso espacial. Como não se sabe o que fazer com ele, Hauser é retirado da sociedade, para que não ameace a paz instituída a partir de prismas "rigorosamente" culturais. Pode-se pleitear que, no envio de Hauser à estrebaria (um cavalo entre cavalos: um cavalo sobre o qual a sociedade imporá os arreios), haja um interdiscurso ${ }^{8}$ com o nascimento de Cristo: "ele veio para os seus e os seus não o receberam", afirma o discurso bíblico. A "gratuidade" e a "ingenuidade" frente a um sistema instituído só pode receber como "prêmio" o exílio, a separação e, por fim, a aniquilação: a crucificação.

Dos 19'36 aos 19'45, enquanto Kaspar permanece no local em que foi abandonado, rigidamente de pé, sem nenhuma iniciativa de se mover ou de falar (frente às coisas às quais não foi apresentado, ele é o ser estranho), a câmera focaliza uma vaca que se encontra amarrada na árvore que existe na praça e os movimentos dela se resumem, pelo fato

\footnotetext{
${ }^{8} \mathrm{O}$ conceito de 'interdiscurso' tem mais de um efeito de sentido e pode remeter a relações intradiscursivas (ou parafrásticas), interdiscursivas (ou polêmicas) ou dialógicas (a relação entre tipos de discurso distintos). Nesse caso, é mais ao terceiro efeito de sentido que o conceito remete.
} 
de estar manietada e presa ao tronco, a traçar círculos ao redor do arbusto. Um conjunto de analogias pode ser realizado, relacionando-se o animal à situação de Hauser. Assim como a vaca, Kaspar se acha preso a um tronco (cultural e imaginário) em torno do qual a sua vida deve se organizar, num movimento servil, escravagista, narcísico, de constante reforço do já sabido e mantido tal como já sabido. Eis a força centralizadora da cultura: como os buracos negros, atrai tudo para o seu centro, num movimento concêntrico e catalisador. Por outro lado, o movimento circular da vaca relembra o sentido percorrido pelos animais no engenho de açúcar e, assim como ela, Kaspar será aquele que movimenta o engenho, triturando, mas sendo triturado por ele, seja pelo trabalho estafante que realiza, seja pela repetição enfática da mesma atitude que não dá margem para que outro mundo possa ser pensado. Por fim, a vaca é o animal que dá o leite que sustenta e dá vida ao homem. Assim como ela, Kaspar acaba de ser posto na situação inescapável de ser alimento e de se alimentar dos que o cercam. Poderse-ia dizer, nesse sentido, que a vida em sociedade é necessariamente antropofágica, pois cada um depende do outro para sobreviver, ao mesmo tempo em que serve como ponto de apoio sobre o qual os outros se amparam: cada um se alimenta do outro, tirando dele vida e sustento. Quer seja, pois, porque será amarrado a um tronco (escravidão), porque está preso às rodas do engenho (trituração) ou porque deve servir de alimento aos que dele se banqueteiam (espoliação), Kaspar está posto na corrente inexorável da destruição e da morte. Esses mesmos efeitos de sentido são reiterados nos cavalos atrelados à carroça (20’28 a 20`40) que fazem parte da cena em que Kaspar aparece imóvel na praça e a vaca está manietada à árvore.

Após passar um tempo na praça sem que ninguém se aproxime e a câmera apenas percorra o trajeto que vai de Kaspar aos cavalos e à vaca, não sem que se dedique a focalizar as pessoas curiosas nas janelas das casas da cidade, dos 21'39 aos 21'49, Kaspar é abordado por um aldeão que busca "dialogar" com ele, sem que, porém, obtenha respostas, dado que o protagonista não fala e está absolutamente apavorado frente ao mundo novo. Hauser achava-se posto na inescapável condição de dizer quem era (todos devem ter um nome que os isole dos demais), de onde vinha (todos devem ter uma identidade geográfica) e que idade possuía (todos devem ter uma determinada ancoragem no tempo). Eis os três eixos dêiticos que parecem não permitir que alguém não se situe, ou seja situado por eles: quem sou (pessoa), de onde venho (lugar) e de quando sou (tempo). Às vezes, pensados como meros recursos dêiticos de ancoragem situacional de um texto, os recursos dêiticos, pensados no plano da vida em sociedade e na discretização de cada um de seus membros, se tornam recursos poderosos de controle e de domínio. São eles que permitem que um processo identificador se aplique a cada um dos indivíduos de uma comunidade, servindo como coordenadas para aquele que deve ser encontrado e, eventualmente, punido por ter transgredido uma regra social. Como aceitar Kaspar numa sociedade organizada em torno dessas formas de percepção do mundo? Neste sentido, dado que ainda não está submetido a coordenadas que o situariam socialmente, a estrebaria e a cadeia na torre de pedra são os únicos lugares adequados para ele. Aos nomes de cidades listados pelo inquisidor e à semelhança de um nome já ouvido, Kaspar "assume" ser de Regensburg, o que parece apaziguar os ânimos do seu observador, que já tem um nome mencionado na carta e um local de proveniência. Caso Kaspar viesse a se tornar um problema, alguns dos elementos de controle seriam sabidos: o seu nome e a sua proveniência.

Não sendo encontrado um lugar adequado (nem pelas autoridades) para que Hauser fosse abrigado (os diferentes não podem viver com os iguais), dos 23'00 aos 24'05, adormecido na estrebaria a que tinha sido conduzido, ele é observado pelos que podem decidir o que fazer com ele: policiais, escrivão, carcereiro e populares. Novamente posto ao lado de um cavalo encilhado, Kaspar é a incógnita que deve começar a ser compreendida para que os 
arreios sociais possam começar a surtir os seus efeitos também sobre ele. Observam-no, analisam-no, tocam-no, despem-no e o revistam para se inteirar de tudo o que seja possível em relação ao personagem insólito que vem "perturbar" a ordem. A carta de apresentação é relida, Kaspar é auscultado e se abre um inquérito onde tudo que diga respeito a ele deve ficar registrado: traços de uma história escrita que, tendo sido lavrada em fogo negro, não mais abandona aquele que cedeu o corpo para ela se inscrever sobre ele. Kaspar é, doravante, o que dizem que ele é: mero objeto de referência. Trata-se, como se vê, de recuperar a história já traçada e, se ela não existe, criar uma outra, social, para que ela passe a constituir aquele que, a seguir, enxergar-se-á pelos olhos dos outros.

Hauser vai aos poucos, e sob duras penas, sendo introduzido numa ordem penitenciária que o faz responder à pergunta de uma dama da sociedade, sobre "Como era a sua vida no cativeiro", com a afirmação "Melhor do que aqui fora": cativeiro por cativeiro, o anterior parecia melhor. Nesse processo de instauração de uma identidade e na marca a ferro em brasa sobre o corpo e Kaspar, dos 27' 50 aos 28'06, os observadores que ali se encontram tentam alimentá-lo com aquilo que lhes parece o melhor alimento que um homem pode desejar, mas Kaspar o cospe, mostrando não gostar do que está provando: no cativeiro, que julga melhor, tinha sido alimentado a pão e água. Mas, para os "algozes", nada mais normal do que a sua alimentação ser igual a de todos. A partir de então, a alimentação e o bom e o ruim ao paladar de Kaspar devem passar a ser o que é tido como o bem do grupo social. Até naquilo que se come e em que, em última instância, poder-se-ia manifestar uma vontade própria e uma individualidade toda peculiar, a marca social se faz presente, transformando a alimentação em um valor de ordem cultural. E cada vez mais Kaspar é transportado para uma cadeia simbólica que o aprisiona e não lhe dá espaços de ruptura na rede fortemente traçada ao seu redor.

Dos 28'10 aos 28'30, antes que Kaspar seja retirado da estrebaria e conduzido para a torre em que residirá, faz-se uma inspeção no seu corpo e ele é vestido com roupas e calçados de tal forma que aquilo que, até então, estava livre de algum investimento de pudor ou despudor, possa ser apresentado publicamente de acordo com a forma prevista pela normalidade que impera ao seu redor. Uma disciplina do corpo, um regime do olhar, um caráter, um espelho, uma decência e uma moral se impõem ao novo membro da sociedade: o seu corpo não lhe pertence mais, ele deverá, futuramente, comportar-se conforme os hábitos culturais dos seus pares. A denúncia de que um conjunto de injunções se abate sobre o corpo do cidadão é ratificada dos 38'20 aos 38'40, quando Kaspar toma banho pela primeira vez, sendo, portanto, submetido a uma penosa atividade, que o faz reclamar da mulher que está lhe dando banho: "Mãe, arranca a pele!" Para além de um suposto valor referencial, pode-se ver, nesse caso, a criação de um efeito de sentido metafórico pois, mais do que a pele corporal, a pele que lhe é arrancada é aquela do trato que costumava destinar ao corpo. A pele cultural que o abrigava é arrancada: Kaspar se acha submetido a um modelo higiênico a que deverá dar atenção daí por diante.

É importante dar atenção ao enunciado proferido pela esposa do hospedeiro, que lhe dá banho: "Não precisa ter vergonha. Estamos sozinhos. Só o bom Deus nos ouve. Não precisa ter medo". Vê-se que esse enunciado mais denuncia quem o profere do que revela o que Hauser poderia estar sentindo. Vergonha de quê, se ele não tem a menor consciência das sobre-determinações culturais impostas sobre o corpo? A vergonha, se existe, está naquele que afirma que ela possa existir: certamente este, estando nu em público sentiria vergonha e sabe que seria submetido à censura, mas não Kaspar, que não percebe o próprio corpo marcado por signos que lhe investem determinados valores. O mesmo vale para 'medo': medo de quê? Kaspar não tem nenhuma razão para senti-lo. Por que estar sozinho é diferente de 
estar em público, tendo que, nesse caso, submeter o corpo a um outro sistema de observação e cuidados? Se, até então, Kaspar não tinha razão alguma para temer ou sentir vergonha de estar com o corpo a descoberto, doravante, à luz do discurso proferido, passará a ter, menos talvez quando estiver sozinho mas, mesmo então, "o bom Deus nos vê" e, dada a magnitude do observador, pode-se tornar ainda mais difícil superar os bloqueios que possam ter-se instalado tiranicamente na consciência de Kaspar (e do homem, sempre é bom lembrar). Isso é corroborado pelo fato de Kaspar, doravante, não mais lidar com o corpo como antes, pois agora ele passa a ser submetido a uma metodologia de cuidados e de higiene: uma "nova" moral o determina, uma nova alma o habita, há coisas a serem escondidas e feitas apenas sob os olhos de Deus.

A nova prisão de Kaspar já era prenunciada dos 34'20 aos 34'50 quando, durante o seu primeiro almoço, lhe é ensinado como sentar à mesa e usar os talheres para se alimentar, ao mesmo tempo em que, ao fundo, a câmera focaliza uma gaiola com um pássaro tentando libertar-se mas, inexoravelmente, indo de encontro às teias metálicas tecidas ao seu redor. Os nós ao redor de Hauser vão se tecendo, enredando-o e colocando-o numa jornada da qual não haverá retorno. A impossibilidade de Kaspar trilhar um caminho diferente daquele já dado pelo grupo social que o "acolhe" num abraço mortal e portentoso se revela ainda em duas outras passagens em que, à tentativa "rebelde" do protagonista de se dar uma identidade peculiar, os fatos lhe mostram que não há mais escapatória: o círculo se fechou e a sua face ficou perdida num lugar qualquer esquecido no tempo. Agora ele é o Outro, um inconsciente coletivo e despótico que o açambarca e lhe dita como deve portar-se.

Uma dessas passagens transcorre no intervalo que vai de 1:09'48 a 1:10'20, momento em que Kaspar revela ao espectador que tinha inscrito seu nome sobre o solo por meio do plantio de agrião e que, durante a noite, alguém tinha entrado ali e pisoteado a plantação, deformando a assinatura lavrada sobre a terra. À tentativa de Kaspar inscrever uma identidade própria sobre um espaço que parece lhe permitir um ato de escritura individual, subjetivo e estilístico, portador de um traçado peculiar, a reação é violenta, pejorativa e esmagadora. O solo emoldurado com 'Kaspar' se torna uma massa informe, amassada e pisoteada de tal forma que elimina o que Hauser tinha tentado fazer: dar-se um nome próprio, embora construído com agrião, planta amarga e que revela o sofrimento de tentar elevar-se da terra e provocar uma irrupção própria. Kaspar (e o homem com ele) não pode lavrar sobre o espaço em branco do papel (ou da terra - de acordo com certas crenças, para os incas, por exemplo, ela é a mãe natureza e é responsável pela criação da vida) uma subjetividade diferenciada, cuja tentativa se faz sobre um cantinho irrisório no fundo do quintal, mas nem a esta existência mínima ele tem direito. $\mathrm{O}$ grupo social se apoderou dele e o reterá em suas malhas, não lhe destinando outro lugar no mundo a não ser aquele permitido ocupar: papéis, posições e representações estatuídas, ou seja, apagamento de uma face. Agora, Kaspar parece ser pura resignação. Enquanto isso, na cena, entra uma garça que acaba de capturar uma perereca, mata o outro animal e o torna seu alimento. Pode-se afirmar que Kaspar é a rã que acaba de se tornar a presa devorada e desintegrada pelas entranhas famélicas que o aprisionaram. Kaspar está sendo engolido por um conjunto de ditames de que não se livrará tão facilmente.

A outra passagem, de uma natureza um pouco distinta da anterior, porque não é um fato que vem do exterior, mas uma constatação de que Kaspar se dá conta (ela resulta de uma percepção do protagonista em relação ao seu estado), ocorre de 1:35'40 a 1:36'00. Encontrando um barril de água, a qual se acha imóvel, o protagonista observa o próprio rosto e, contrariamente a Narciso que se apaixona pelo que vê, passa a mão sobre a superfície da água, fazendo-a mover-se e, com isso, desfaz a inteireza da imagem. Um rosto embaçado, 
uma imagem difusa, um contorno flutuante, um ser irreconhecível se revela então. Kaspar parece estar-se dando conta de que não há no mundo lugar para ele: tal qual o espelho feito em cacos, ele deixou de ter um princípio de completude e integralidade: ele é o conjunto de fragmentos que foi levado a ser. Nada mais tem de seu: a sociedade o reduziu a cacos. Ele foi reduzido ao camelo que, dos 55'35 aos 55'57, é mostrado andando sobre os joelhos, numa posição desconfortável e domesticada, tendo perdido a referência do seu modo de andar natural: contra o olhar altivo que o camelo poderia ter, dada a sua altura, que lhe permite olhar de cima, ele está obrigado (assim como Kaspar e os homens) a andar de joelhos e se curvar à domesticação e ao fardo pesado que lhe foi imposto sobre o dorso, fardo que vem de um conjunto de discursos que se imprimem sobre cada um e que se revelam nos objetos que se encontram nos bolsos de Kaspar, quando ele é encontrado (29'00 a 30'05): um livro de orações, um terço com cruz de metal e uma papeleta com folhas de ouro (perceba-se a fusão "ilógica" entre devoção e ganância): mescla de religião e dinheiro (ambos fontes de poder). Eis o que parece ditar a trilha a ser seguida pela comunidade humana: doutrinada de um lado, ideologizada de outro. Que saída resta a Kaspar se não a submissão e a aceitação de poderes tão fortemente constituídos e reforçados pela rede de relações que se tecem ao seu redor por tudo e por todos? Hauser deveria estar definitivamente domado e dominado.

Vendo o que se passa por meio de um olhar questionador, taciturno e cético, ele ainda expressa alguns questionamentos mas, por ser diferente (ele é o personagem circense que é mostrado como aberração) e não se submeter irrestritamente ao que é proposto, Kaspar é morto: uma chaga no peito, do lado direito, de onde escorre um sangue vermelho e viscoso. Como ele não se apossou da cultura, permitindo que ela se apoderasse dele, Kaspar deve morrer: seja a morte física ou simbólica (1:38'24 e 1:38'40). Ao espectador, fica a tarefa de responder ao enigma que Hauser propõe na sua história. De 1:42'00 a 1:43'10, ele relata que, nos seus sonhos, vê camelos e pessoas em caravana atravessando o deserto. Num determinado momento, param achando que o caminho terminou e não há para onde ir (há, aqui, uma alusão ao êxodo do Egito por parte dos israelenses conduzidos por Moisés - a festa de Pentecostes incluía, além da ação de graças pelos dons da terra, o objetivo de reforçar a memória da libertação da escravidão no Egito e o cuidado com a obediência aos estatutos divinos). O cego que os guia (perceba-se a ironia que se constrói neste momento: o responsável pela condução do grupo é alguém que não enxerga. Ao mesmo tempo, poder-seia pensar que o enunciador Herzog esteja propondo que o mundo que aí está deveria ser revisto sob a perspectiva de alguém ainda não cegado pelas injunções culturais. Kaspar Hauser (quem sabe?) lhes diz que o que têm à frente é apenas uma montanha e, do outro lado, existe um espaço para a criação de uma cidade, onde os viajantes passam a viver. O problema de Kaspar é não poder prever que futuro espera a comunidade. De certa forma, o que ele está propondo é se será possível que a civilidade construída se refaça e permita uma outra convivência entre os homens: eles estariam dispostos a abrir mão das crenças, benesses, formas de controle, modos de domínio, injunções culturais, conjunto de culpas e sistemas de hierarquia que desenvolveram?

\section{A título de conclusão da análise}

Herzog parece propor, dos 44'36 aos 44'50, que o espectador se emocione com a cena em que o bebê chora no seu berço e é acalentado por Kaspar que, a convite da mãe, o toma nos braços, o acaricia e o faz sentir prazer. Estaria nas mãos de uma mulher e de um ente estrangeiro no seu próprio solo a saída para a sociedade opressora, dominadora e controladora existente? Estariam os homens dispostos a abrir mão de privilégios e, como Kaspar, acolher o 
outro nos braços e lhe dar tempo, atenção e aceitação? Estariam dispostos a pensar sobre a questão feita por Kaspar: "Esses gritos assustadores ao redor são o que chamam silêncio?".

Desde que Kaspar é descoberto, o escrivão se propõe a escrever "Um belo registro. Um registro perfeito. Vou lavrar um registro como ninguém viu até hoje!” (57'45 a 57'56). Se, antes, podia-se fazer a hipótese de que ele seria o porta-voz de Herzog, no sentido de que faria um "belo registro" que deslindasse as razões culturais de Kaspar ser "anormal" e não conseguir se adequar à "moral" vigente, pois havia se encontrado com uma sociedade castradora, não conseguindo incorporar o que era esperado de cada um de seus membros, no fim, quando o escrivão, após acompanhar a autópsia de Kaspar que constata que ele tinha uma deformidade cerebral, repete o discurso laudatório sobre a sua atividade, afirmando outra vez que irá produzir "Um lindo registro. Um registro perfeito. Lavrarei um registro sobre a deformidade encontrada em Hauser. Finalmente temos a melhor explicação que podíamos achar sobre este estranho personagem" (1:48'10 a 1:48'30): pode-se constatar agora que ele é realmente um fiador de Herzog, cuja atividade, porém, deve-se muito mais à revelação do seu distanciamento irônico frente ao cientificismo, para o qual o homem não seria mais do que um conjunto de reações e um produto de causas naturais, que o definiriam cabalmente quanto à capacidade de produzir conhecimento e compreender, por exemplo, Matemática, Lógica e Religião. A dificuldade de Kaspar com estes saberes é explicada no final pelo fato de o hemisfério esquerdo do seu cérebro ser menor do que o da direita. Eis a chave explicativa que cega o olho para causas outras que não sejam de ordem natural. A questão proposta por Herzog pode ser: o cérebro de Kaspar é diferente e isso o torna incapaz para determinadas coisas ou é incapaz porque foi submetido a um processo cultural que o levou a desenvolver certas aptidões e não outras? O cineasta parece inclinar-se pela segunda via, posicionando-se contra as teses das determinações naturais das competências do homem.

Postula-se, pois, que o escrivão seja um porta-voz de Herzog, a quem compete relatar o lento, mas inexorável, aprisionamento de Kaspar (e do homem) ao modus vivendi do seu grupo. Parece que Herzog fez um belo registro daquilo a que se propunha: chamar a atenção para a sociedade carcerária e tribunalizadora que caracteriza as culturas humanas. Kaspar se pergunta (e o homem deveria fazê-lo com ele) se o futuro dos homens pode ser diferente daquele para o qual eles parecem encaminhar-se. Ele se interroga sobre se os homens estarão dispostos a desconstruir as cadeias que construíram para se auto-aprisionar e das quais parecem não mais ter saída, ou seja, se eles estarão um dia livres de cadeias.

\section{Como conclusão provisória do estudo}

Este estudo, mistura heteróclita de artigo científico e ensaio, embora não seja nem uma coisa nem outra, se for remetido à forma canônica desses gêneros, procurou chamar a atenção para alguns elementos constitutivos do filme e pleitear uma unidade de sentido que os englobaria, um foco de coerência e uma unidade temática de sentido. Como se comentou, a motivação desencadeadora da reflexão alinhavada é devida ao comentarista da capa do DVD, para quem a questão-problema do enunciador seria: é possível levar alguém a adquirir uma determinada cultura, se vier a ter contato com ela num período da sua vida muito avançado cronologicamente? Buscou-se defender o ponto de vista de que não é necessariamente esta a questão central sobre a qual Herzog (o enunciador) se debruça, mas a indicação de que a entrada numa cultura se faz por meio de processos violentos de imposição de atitudes, comportamentos, crenças e valores, não havendo espaço para que a diferença, a diversidade e a pluralidade encontrem guarida. Nesse sentido, o filme não está preocupado em responder se, depois de certa idade, as pessoas ainda estariam em condições de serem aculturadas e serem 
inseridas completamente nos hábitos culturais de um grupo. Pode-se pleitear, e este foi o caminho traçado, que Herzog (o filme, o enunciador) se debruça sobre outra problemática: a demonstração de que a vida em sociedade é constituída por um conjunto de princípios, normas e regras que se abatem sobre todos e os impede de viverem à sua maneira e estabelecerem miradas diferentes daquelas já estatuídas.

O percurso do filme, portanto, poderia ser postulado como sendo a revelação de que o caminho do homem na sociedade é aquele que o leva da natureza à cultura, da infância à plenitude social, da "rebeldia" à domesticidade, isto é, de uma cadeia a outra. Estáse fazendo uma generalização, portanto, de que Kaspar Hauser e o grupo social em que fortuitamente ele acabou sendo colocado constituem a construção em baixo relevo, a revelação metonímica e a denúncia microscópica do que acontece com cada homem na caminhada que o transforma de ser biológico, fisiológico e instintivo - indivíduo - em ser social e ideológico - sujeito. De um conjunto de coerções a que se encontra submetido, dada a sua natureza animal, sem deixá-las e lado, ele passaria a um outro conjunto de restrições, desta vez, de natureza social, que o controlam, limitam e determinam em suas atividades. A situação vivida por Kaspar Hauser seria, nesse sentido, um caso particular e pontual (ficcional, possivelmente) que se pretende universal: a revelação da coerção e rarefação social que se abate sobre os homens no processo de aculturação a que são submetidos. Enfim, Kaspar Hauser seria uma metáfora de qualquer homem que, posto em sociedade, não teria outro "destino" a não ser viver aprisionado.

Como o leitor deve ter percebido, fez-se a opção por indicar na primeira nota apenas os maiores débitos teóricos para que a análise apresentada pudesse ser esboçada, deixando-se de, como é praxe, arrebanhar a fundamentação teórica numa fase inicial do texto, para, depois, usá-la ao efetuar o movimento analítico. Optou-se por agir dessa maneira para ter um espaço maior de discussão em relação ao objeto focalizado e poder dar uma maior sustentação argumentativa à tese que se queria defender. Espera-se que isso não traga maiores perturbações ao leitor e que a discussão apresentada possa ser julgada à luz da sua submissão ao crivo do confronto entre o filme, a análise e os amparos teóricos assumidos.

\section{Referências Bibliográficas}

AUMONT, Jacques. Tradução de Estela dos Santos Abreu e Cláudia C. Santoro. A imagem. 7.ed. Campinas, SP: Papirus, 1993.

BAKHTIN, Mikhail. Discurso na vida e discurso na arte. Tradução de Carlos Alberto Faraco e Cristóvão Tezza. New York: Academic Press, 1976, 23p (inédito).

BERGER, Peter L. Perspectivas sociológicas: uma visão humanística. Tradução de Donaldson M. Garschagen. 26.ed. Petrópolis: Vozes, 2004.

BOURDIEU, Pierre. A dominação masculina. Tradução de Maria Helena Kühner. Rio de Janeiro: Bertrand Brasil, 1999.

CASTORIADIS, Cornelius. A instituição imaginária da sociedade. Tradução de Guy Reynaud. 6.ed. Rio de Janeiro: Paz e Terra, 1982.

CHARTIER, Roger. A história cultural: entre práticas e representações. Tradução de Maria Manuela Galhardo. Rio de Janeiro: Difel, 1990.

DONDIS, D. A. Sintaxe da linguagem visual. Tradução de Jefferson Luiz Camargo. 2.ed. São Paulo: Martins Fontes, 1997.

ECO, Umberto. O signo de três. Tradução de Silvana Garcia. São Paulo: Perspectiva, 1991. Lector in fabula. Tradução de Attílio Cancian. São Paulo: Perspectiva, 1986. 
ELIAS, Norbert e SCOTSON, John L. Os estabelecidos e os outsiders: sociologia das relações a partir de uma pequena comunidade. Tradução de Vera Ribeiro. Rio de Janeiro: Jorge Zahar Editor, 2000.

FOUCAULT, Michel. Vigiar e punir. Tradução de Raquel Ramalhete. 19.ed. Petrópolis: Vozes, 1999.

$\overline{\text { Loyola, }} 1996$.

A ordem do discurso. Tradução de Laura Fraga de Almeida Sampaio. São Paulo: 1999.

. Microfísica do poder. Tradução de Roberto Machado. 14.ed. Rio de Janeiro: Graal,

. Isto não é um cachimbo. Tradução de Jorge Coli. Rio de Janeiro: Paz e Terra, 1988.

GOFFMANN, Erving. A representação do eu na vida cotidiana. Tradução de Maria Célia Santos Raposo. 14.ed. Petrópolis: Vozes, 2007.

HALL, Stuart. A identidade cultural na pós-modernidade. Tradução de Tomaz Tadeu da Silva e Guacira Lopes Louro. 8.ed. Rio de Janeiro: DP\&A, 2003.

LAPLANTINE, François \& TRINDADE, Liana. O que é o imaginário. São Paulo: Brasiliense, 1997.

MAINGUENEAU, Dominique. Gênese dos discursos. Tradução de Sírio Possenti. Curitiba: Criar Edições, 2005.

MANGUEL, Alberto. Lendo imagens: uma história de amor e ódio. Tradução de Rubens

Figueiredo, Rosaura Eichemberg e Cláudia Strauch. 2.ed. São Paulo: Companhia das Letras, 2001.

POSSENTI, Sirio. Sobre as noções de efeito de sentido. In: Cadernos da FFC. $n^{0}$. 2. v.6. p. 1 a 11, Marília: Editora da UNESP, 1997.

SANTAELLA, Lucia. Semiótica aplicada. São Paulo: Pioneira Thomson Learning, 2002.

SARTORI, Giovanni. Homo videns: televisão e pós-pensamento. Tradução de Antonio Angonese. São Paulo: Edusc, 2001.

THOMPSON, Edward Palmer. Costumes em comum: estudos sobre a cultura popular tradicional. Tradução de Rosaura Eichemberg. 2.ed. São Paulo: Companhia das Letras, 1998. 